\title{
Effects of Insulin and NSILA on Adipocytes of Normal and Diabetic Rats: Receptor Binding, Glucose Transport and Glucose Metabolism*
}

\author{
E. Schoenle, J. Zapf, and E. R. Froesch \\ Metabolic Unit, Department of Medicine, Kantonsspital Zürich, Switzerland
}

Summary. Isolated fat cells from normal and streptozotocin-diabetic rats were compared with respect to metabolic indices (glucose-uptake, 3-0-methylglucose efflux) with and without stimulation by insulin and nonsuppressible insulin-like activity (NSILA). In addition, binding studies were carried out with these two hormones. Basal ${ }^{14} \mathrm{C}$-glucose oxidation and incorporation into lipids was decreased in diabetic cells and their response to insulin and NSILA was greatly reduced. Basal efflux of 3-0-methylglucose from diabetic cells was somewhat faster than from normal cells. The response to insulin and NSILA was less than in normal cells and it was delayed. The apparent number of insulin binding sites as well as their affinity for insulin was increased in diabetic cells. In contrast, the apparent number of binding sites for NSILA was decreased in diabetic cells and their affinity for NSILA was increased. In normal cells insulin enhanced binding of ${ }^{125}$ I-NSILA more markedly than in diabetic cells. These findings show that the rate-limiting step of impaired glucose metabolism (oxidation and lipogenesis) in diabetic fat cells is beyond the interaction of the hormone with the receptor. They suggest that the apparent number of hormone receptors (insulin, NSILA) on the cell membrane is regulated individually for each binding site.

Key words: Insulin, NSILA, adipocytes, diabetic rats, insulin-receptor, NSILA-receptor, glucose transport, glucose metabolism.

Adipose tissue from diabetic rats responds poorly to insulin. Thus, glucose uptake and oxidation are much less stimulated by insulin in diabetic than in

* Supported by grant No: $3.595-0.72$ from the Swiss National Fonds normal adipose tissue $[1,2,3]$; in diabetic adipose tissue insulin is also less effective in reducing epinephrine-induced FFA release [4].

The possibility has been envisaged that the poor metabolic response of diabetic adipose tissue to insulin might be related to changes in the number and/or affinity of the insulin receptor. Vann Bennett and Cuatrecasas [5] found that fat cells from streptozotocin-diabetic rats displayed the same specific binding and affinity of ${ }^{125}$ I-labelled insulin as fat cells from normal rats. A decrease in the number, but not in the affinity of the insulin receptor has been described in fat cells from obese, hyperglycaemic mice $[6,7]$ and in adipocytes and monocytes from patients with maturity onset diabetes $[8$, 9]. Recently, Hepp [10] reported that the number of insulin receptors was increased in liver membranes from spontaneously diabetic chinese hamsters.

In this paper we have tried to re-evaluate some of the binding characteristics of the insulin receptor in adipocytes from both normal and streptozotocindiabetic rats in conjunction with the effects of insulin on glucose transport and glucose metabolism. In addition, these data were compared to those obtained with nonsuppressible insulin-like activity (NSILA). This peptide mimics all the effects of insulin both in vitro and in vivo $[11,12]$ and has recently been shown to bind to the insulin receptor as well as to a separate NSILA-receptor of rat adipocytes [15]. Recently Rinderknecht and Humbel have shown that NSILA consists of two molecular species of the same MW $(\sim 6000)$ and a slightly different amino acid composition [13]. More recently the same authors have determined the sequence of the first 30 amino acids. NSILA has now been termed insulinlike growth factor: IGF [14].

We asked the following questions: 1 . How does NSILA affect glucose transport and metabolism in fat cells from diabetic rats? 2. Does insulin deficien- 
cy cause any changes in binding of ${ }^{125}$ I-labelled NSILA to adipocytes? 3. How does NSILA compare with insulin in these respects?

\section{Materials and Methods}

Male Zbz-Cara (formerly Osborne Mendel) rats, weighing between 110 and $130 \mathrm{~g}$ were used. They were fed NAFAG chow (No 890, NAFAG, Gossau, Switzerland) consisting of $65 \%$ cereals, $20 \%$ protein and $5 \%$ fat. Diabetes was induced by intravenous administration of $70 \mathrm{mg} / \mathrm{kg}$ of streptozotocin. 4-5 days after the injection the animals were sacrificed. During that time they lost between 5 and $10 \%$ of their body weight. The fat pad weight fell by between 40 and $50 \%$. Blood sugar values ranged from 300 to $500 \mathrm{mg} / 100 \mathrm{ml}$. Most of the animals were ketotic, when the urine was tested with Ketostix (Ames). Whale insulin $(24 \mathrm{U} / \mathrm{mg}$, identical amino-acid sequence to porcine insulin) and partially purified NSILA were kindly supplied by Drs. E. Rinderknecht and R. E. Humbel. The biological activity of NSILA was standardized in the rat fat pad assay with insulin as the reference [24]. Molar concentrations of different preparations of NSILA were calculated on the basis of a specific activity of $400 \mathrm{mU} / \mathrm{mg}$ and a molecular weight of 6000 for pure NSILA [13]. Human serum albumin (HSA) was supplied by the Swiss Red Cross, Bern. It was dialysed extensively against 3 changes of distilled water before use and filtered by sterile filtration. Streptomycin $(5 \mathrm{mg} / 100 \mathrm{ml})$ and penicillin $(10 \mathrm{IU} / 100 \mathrm{ml})$ were added.

3-0-methylglucose was from Sigma, U- ${ }^{14} \mathrm{C}-3-0-$ methylglucose, $1-{ }^{14} \mathrm{C}$-glucose, $\mathrm{U}-{ }^{14} \mathrm{C}$-glucose, ${ }^{3} \mathrm{H}$ inulin were purchased from Amersham, Radiochemical Centre.

The iodination procedure for insulin and NSILA ( $200 \mathrm{mU} / \mathrm{mg}, 50-60 \%$ pure) as well as the properties of the labelled NSILA preparation have been described previously [16]. Both labelled peptides contained less than one atom of iodine per molecule.

\section{Experimental Procedures}

Fat cells were prepared from epididymal rat fat pads by the method of Rodbell [17] using crude collagenase (Worthington Biochemical Corp.).

\section{Metabolic Studies}

$2-3.5 \times 10^{5}$ fat cells $(18000 \pm 1500$ cells/mg dry weight for normal rats; $48000 \pm 6000$ cells/mg dry weight for diabetic rats; 10 experiments each) were incubated for $45 \mathrm{~min}$ at $37^{\circ} \mathrm{C}$ in $1 \mathrm{ml}$ of KrebsRinger-bicarbonate buffer containing $1 \mathrm{~g} / 100 \mathrm{ml}$ HSA, $20 \mathrm{mg} / 100 \mathrm{ml}$ of glucose, $1{ }^{14} \mathrm{C}$ - or $\mathrm{U}-{ }^{14} \mathrm{C}$ glucose $(0.1 \mu \mathrm{Ci})$ and different concentrations of insulin or NSILA $(3.8 \mathrm{mU} / \mathrm{mg}) .{ }^{14} \mathrm{CO}_{2}$ production from $1-{ }^{14} \mathrm{C}$-glucose and lipogenesis from $\mathrm{U}_{-}{ }^{14} \mathrm{C}$-glucose were determined as described by Gliemann $[18,19,20]$.

\section{Glucose Transport Studies}

The total amount of fat cells prepared from the fat pads of 10 to 15 rats was divided into 3 aliquots. Two aliquots were preincubated without hormone addition, to the third aliquot insulin or NSILA (100 $\mu \mathrm{U} / \mathrm{ml}$ ) was added. Preincubation was carried out under gentle stirring for $40-60 \mathrm{~min}$ at $37^{\circ} \mathrm{C}$ in $4 \mathrm{ml}$ of Krebs-Ringer bicarbonate buffer $/ 1 \mathrm{~g} / 100 \mathrm{ml}$ HSA, containing $30 \mathrm{mmol} / 1 \mathrm{3}-0$-methylglucose and 15-20 $\mu \mathrm{Ci}$ of $\mathrm{U}^{14} \mathrm{C}-3-0$-methylglucose. After preincubation two $300 \mu \mathrm{l}$ aliquots of each of the cell suspensions were gently centrifuged (Beckman microfuge B) through a layer of $50 \mu \mathrm{l}$ of dinonylphthalate in $400 \mu \mathrm{l}$ plastic microtubes (Milan Instruments, Geneva). The cell layers were rapidly resuspended in $3 \mathrm{ml}$ of the same buffer containing $30 \mathrm{mmol} / 1$ cold 3-0-methylglucose and $10 \mu \mathrm{Ci}$ of ${ }^{3} \mathrm{H}$-inulin. Incubation was continued under constant stirring in the presence or absence of $100 \mu \mathrm{U} / \mathrm{ml}$ of insulin or NSILA. After different time intervals $300 \mu \mathrm{l}$ aliquots were pipetted into $400 \mu \mathrm{l}$ microtubes and centrifuged at high speed $(\sim 10000 \mathrm{~g}, 20 \mathrm{~s}$, Beckman Microfuge B) through $50 \mu l$ of dinonylphthalate (modified according to reference 21). The tops of the microtubes containing the cell layer were cut off and counted for radioactivity in $5 \mathrm{ml}$ of Instagel (Packard) in a beta-counter (Tricarb, Packard). The extracellular water was calculated from the ratio between the ${ }^{3} \mathrm{H}$-inulin radioactivity contained in the cell layer after centrifugation and the ${ }^{3} \mathrm{H}$-inulin radioactivity contained in $300 \mu \mathrm{l}$ of the cell suspension; it varied between 0.2 and $0.3 \mu l$ per $2 \times 10^{5}$ cells.

\section{Binding Studies}

Fat cells $\left(2-3.5 \times 10^{5}\right)$ were incubated in a total volume of $0.5 \mathrm{ml}$ of Krebs-Ringer bicarbonate buffer $/ 1 \mathrm{~g} / 100 \mathrm{ml}$ HSA containing $20 \mathrm{mg} / 100 \mathrm{ml}$ of glucose, ${ }^{125}$ I-labelled insulin $(\sim 20 \mu \mathrm{U}, \sim 2 \times$ $\left.10^{5} \mathrm{cpm}\right)$ or ${ }^{125}$ I-labelled NSILA $(\sim 0.9 \mu \mathrm{U}, \sim 2 \times$ $\left.10^{5} \mathrm{cpm}\right)$ and different amounts of unlabelled insulin or NSILA.

After incubation for $45 \mathrm{~min}$ at $37^{\circ} \mathrm{C} 300 \mu \mathrm{l} \mathrm{ali-}$ 

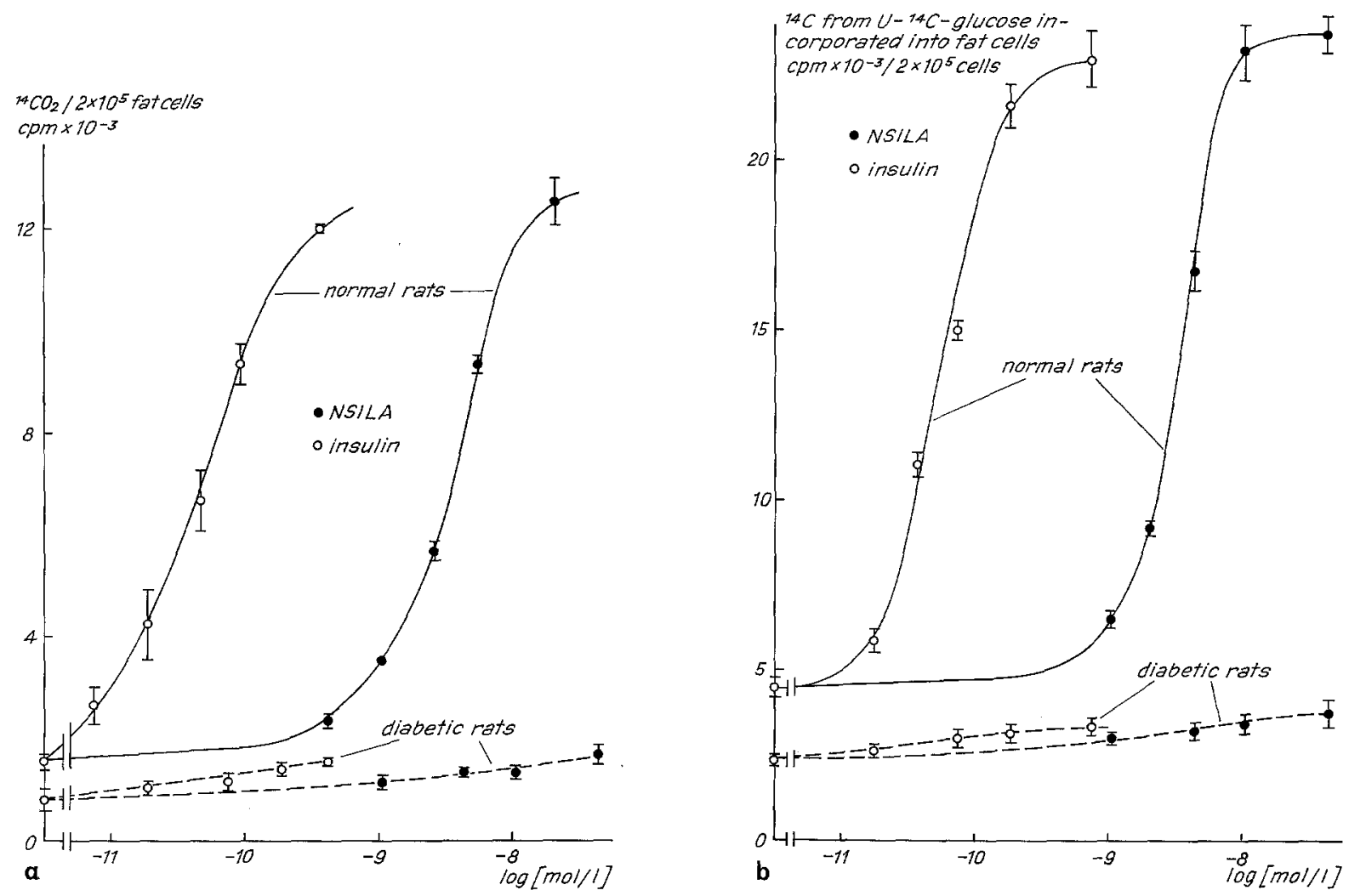

Fig. 1. a Oxidation of $1{ }^{14} \mathrm{C}$-glucose in fat cells of normal and diabetic rats stimulated by insulin and NSILA. The glucose concentration was $1 \mathrm{mmol} / \mathrm{l}$, the incubation at $37^{\circ} \mathrm{C}$ lasted for $1 \mathrm{~h}$. Basal oxidation and stimulation by both hormones was considerably decreased in diabetic cells. Each point gives the mean of two different experiments carried out in duplicate and the brackets indicate the upper and the lower value of the two experiments. b Basal and stimulated lipogenesis (insulin, NSILA) from U- ${ }^{14} \mathrm{C}$-glucose in fat cells of normal and diabetic rats. The glucose concentration was $1 \mathrm{mmol} / 1$, the incubation at $37^{\circ} \mathrm{C}$ lasted for $45 \mathrm{~min}$. Basal glucose incorporation as well as stimulation by both hormones was considerably decreased in diabetic cells. Each point gives the mean of 3 different experiments carried out in duplicate. The brackets indicate the S. E.M.

quots of the cell suspension were pipetted into 400 $\mu \mathrm{l}$ microtubes and centrifuged for $20 \mathrm{~s}$ at $10000 \mathrm{~g}$ through $50 \mu \mathrm{l}$ of dinonylphthalate, which separates radioactivity bound to the cells from unbound label. The tops of the tubes were cut off and counted in a gamma-counter (Nuclear Chicago).

\section{Results}

\section{Metabolic Studies}

As shown in Figure $1 \mathrm{a}$ insulin and NSILA much less effectively stimulated glucose oxidation in diabetic than in normal fat cells. Maximal stimulation by both hormones was only twofold in diabetic, but 8 to 10 -fold in normal cells. Basal ${ }^{14} \mathrm{CO}_{2}$-production was also lower in diabetic adipocytes. As shown earlier [15] NSILA is approximately 60 times less active than insulin on normal cells. The same also holds true for diabetic cells. In both conditions halfmaximal stimulation of ${ }^{14} \mathrm{CO}_{2}$-production was observed at $\sim 5 \times 10^{-11} \mathrm{M}$ insulin and $\sim 3 \times 10^{-9} \mathrm{M}$
NSILA. Essentially the same results were obtained when lipogenesis from $\mathrm{U}-{ }^{14} \mathrm{C}$-glucose was measured in normal and diabetic fat cells under the influence of insulin and NSILA (Fig. 1b). In diabetic adipocytes basal lipogenesis in the absence of hormone was only one half of that in normal adipocytes. The potency ratio between the two hormones was the same as that found for glucose oxidation.

\section{Transport Studies}

In Figures 2 and 3 the effects of insulin and NSILA on the efflux of $\mathrm{U}_{-}{ }^{14} \mathrm{C}-3-0$-methylglucose from normal (Fig. 2) and diabetic adipocytes (Fig. 3) are compared. Efflux in the absence of hormone seemed to follow first-order kinetics, since a semi-logarithmic plot of the radioactivity contained in the separated cell layer after different time intervals gave a straight line (not shown). From this the radioactivity at zero-time could be extrapolated.

Preincubation of the cells with $100 \mu \mathrm{U} / \mathrm{ml}$ of insulin (Fig. $2 \mathrm{a}$ ) or NSILA (Fig. 2b) resulted in an 

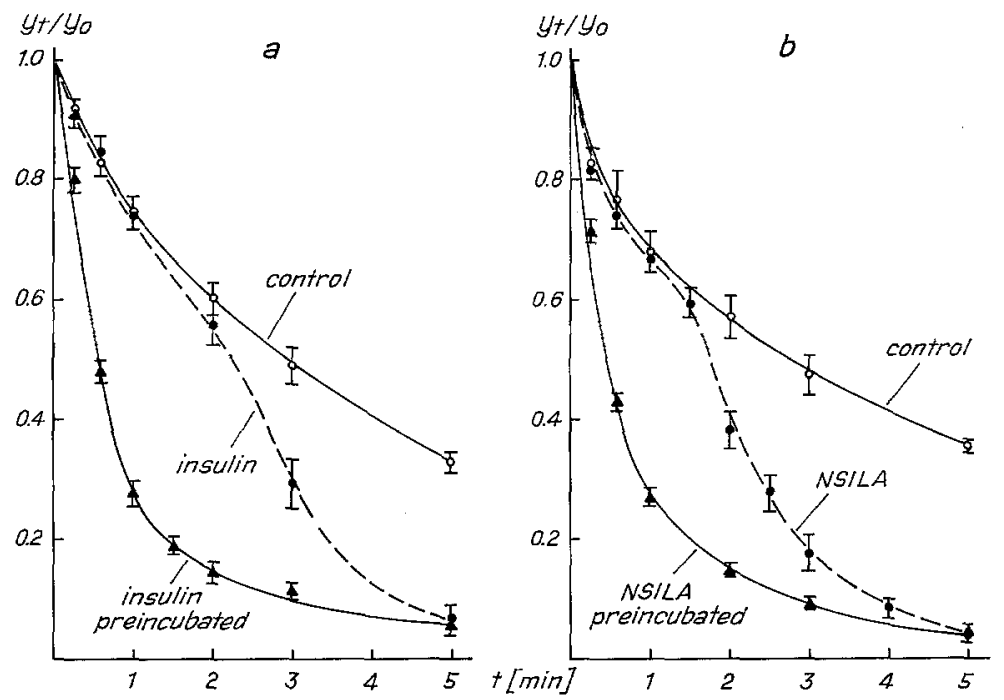

Fig. 2. Efflux of 3-0-methylglucose from fat cells of normal rats. $\mathrm{O}-\mathrm{O}$ basal efflux; $\bullet$ efflux after addition of the hormone $(100 \mu \mathrm{U} / \mathrm{ml})$ to the incubation medium at time $0 ; \boldsymbol{\Delta}-\boldsymbol{\Delta}$ efflux from cells which were preincubated in the presence of the hormone $(100 \mu \mathrm{U} / \mathrm{ml})$. The value obtained after 8 min of incubation corresponded to the extracellular water space (between 40 and $60 \%$ of the total counts as determined with ${ }^{3} \mathrm{H}$-inulin). This value was subtracted. Yt $(t=0)$ was extrapolated as explained under methods. NSILA with $44 \mathrm{mU} / \mathrm{mg}$ protein was used. Each point represents the mean of 3 to 7 experiments and the brackets give the S. E.M.

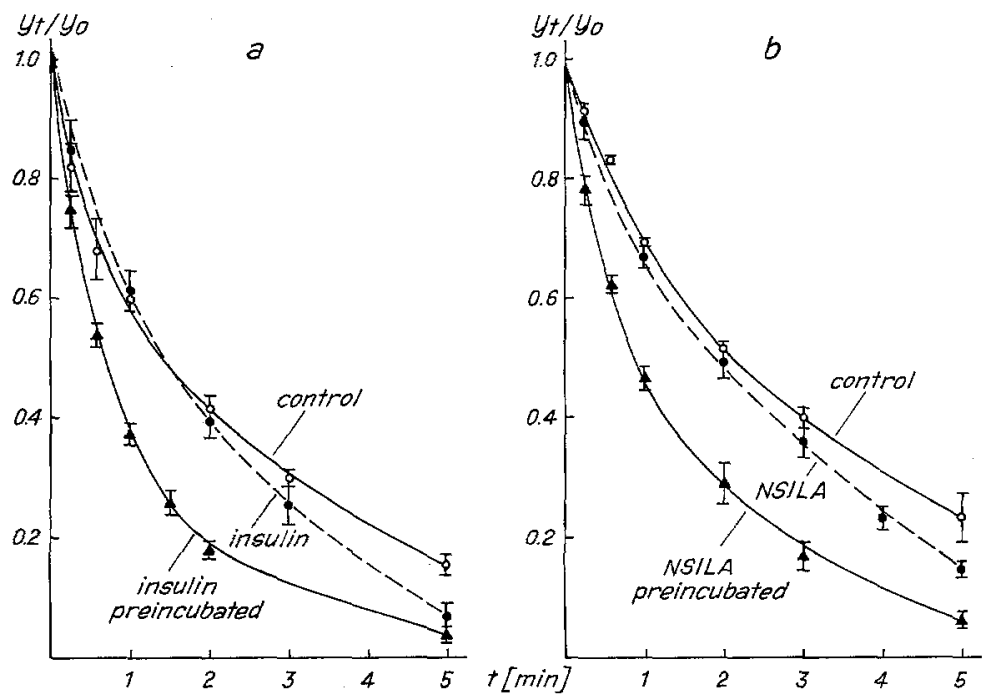

Fig. 3. Efflux of 3-0-methylglucose from fat cells of diabetic rats. The experimental conditions and computations were the same as explained in the legend of Fig. $2(n=3-6)$

immediate rapid efflux of the labelled sugar. The time course was nearly identical for both hormones: after $30 \mathrm{~s}$ half of the label initially present in the intracellular space had left the cells, and after $3 \mathrm{~min}$ only $10 \%$ of the label was intracellular. If preincubation of the cells was carried out in the absence of hormone, and insulin (Fig. 2 a) or NSILA (Fig. 2 b) were added at zero-time of the efflux-experiment, a lag period of $1.5-2 \mathrm{~min}$ was observed. During that time efflux followed the time-course of the control, before it took off at an enhanced rate.

When basal and hormone-stimulated efflux rates from normal and diabetic fat cells were compared, clear-cut differences could be recognized: 1 . efflux of labelled 3-0-methylglucose in the absence of hormone (control) appeared to proceed faster in diabetic than in normal cells (half-life $1.5-2 \mathrm{~min}$ compared to $\sim 3 \mathrm{~min}$ ). 2. When insulin (Fig. $3 \mathrm{a}$ ) or NSILA (Fig. $3 \mathrm{~b}$ ) were added at the beginning of the efflux experiment, without preincubation of the cells in the presence of either of the hormones, the time course of the efflux no longer appeared to be biphasic, but followed more or less that of the control, at least over the first $3 \mathrm{~min}$ of the experiment. After that a slight enhancement of the efflux rate by the hormone seemed to occur. In contrast, the time course of efflux was very similar to that observed in normal fat cells when the cells were preincubated with one of the two hormones (Figs. $2 \mathrm{a}$ and $3 \mathrm{~b}$ ).

From these data it can be concluded that insulin and NSILA stimulated 3-0-methylglucose transport in both normal and diabetic fat cells, but that this stimulatory effect was delayed in diabetic fat cells. Although diabetic fat cells were smaller than normal fat cells the delayed action of insulin and NSILA cannot be attributed to different intracellular water spaces. Using ${ }^{3} \mathrm{H}$-inulin as extracellular marker and $\mathrm{U}-{ }^{14} \mathrm{C}-3-0$-methylglucose for measuring the total accessible water space these were found not to differ significantly. The intracellular water space in normal 
fat cells was $0.21 \pm 0.02 \mu \mathrm{l}$ per $2 \times 10^{5}$ cells and in diabetic fat cells $0.18 \pm 0.02 \mu \mathrm{l}$ per $2 \times 10^{5}$ cells.

\section{Binding Studies}

Binding of ${ }^{125}$ I-labelled insulin to normal and diabetic fat cells and displacement by unlabelled insulin or NSILA are shown in Figure 4. Specific binding of labelled insulin was $1.7 \times$ higher in the diabetic than in the normal fat cells $\left(2.12 \%\right.$ per $2 \times 10^{5}$ diabetic cells compared to $1.25 \%$ per $2 \times 10^{5}$ normal cells). As demonstrated earlier for normal adipocytes [15], unlabelled NSILA was much less potent than unlabelled insulin in displacing labelled insulin from diabetic fat cells. The apparent $\mathrm{K}_{\mathrm{D}^{-}}$ values determined for normal fat cells in these experiments were $3.5 \times 10^{-9} \mathrm{M}$ for insulin and $3.3 \times$ $10^{-7} \mathrm{M}$ for NSILA. These values are higher than those reported earlier, due apparently to the fact that the incubation temperature was $37^{\circ} \mathrm{C}$ compared to $24^{\circ} \mathrm{C}$ in our earlier studies. The potency ratio between NSILA and insulin at $37^{\circ} \mathrm{C}$ was also higher $(1: 94)$ than in the previous experiments carried out at $24^{\circ} \mathrm{C}(1: 35)$. Apart from increased binding of ${ }^{125} \mathrm{I}$-labelled insulin to diabetic fat cells there was a concomitant small increase in the apparent affinity of the insulin binding site for insulin (app. $\mathrm{K}_{\mathrm{D}} 1.8 \times 10^{-9} \mathrm{M}$ ), whereas it remained the same for NSILA $\left(3.1 \times 10^{-7} \mathrm{M}\right)$.

Three further differences between normal and diabetic fat cells became apparent when bindingdisplacement experiments were carried out with labelled NSILA (Fig. 5): 1. In contrast to the increased specific binding of labelled insulin, specific binding of labelled NSILA was decreased in diabetic fat cells $\left(0.22 \%\right.$ per $2 \times 10^{5}$ diabetic cells compared to $0.38 \%$ per $2 \times 10^{5}$ normal cells). 2 . The decrease in specific binding was accompanied by an increase of the apparent affinity of the NSILA binding sites in diabetic fat cells. Half-maximal displacement was caused by $1.8 \times 10^{-9} \mathrm{M}$ NSILA compared to $4.2 \times$ $10^{-9} \mathrm{M}$ in normal fat cells. Again, as in the insulin binding experiments, the current apparent $K_{D}$-value is higher than the one reported earlier, which was determined at $24^{\circ} \mathrm{C}$ [15]. 3. As shown earlier [15] increasing concentrations of unlabelled insulin caused increased binding of labeiled NSILA. In normal fat cells this insulin-induced increase in NSILAbinding was greater $(+178 \%$ in the presence of $1 \mathrm{mU} / \mathrm{ml}$ of insulin) than in diabetic cells $(+46 \%$, Table 1).

\section{Discussion}

The responsiveness of diabetic adipose tissue and of fat cells to insulin is reduced $[1,2,3,5]$. Attention was again focussed on this phenomenon when it be-

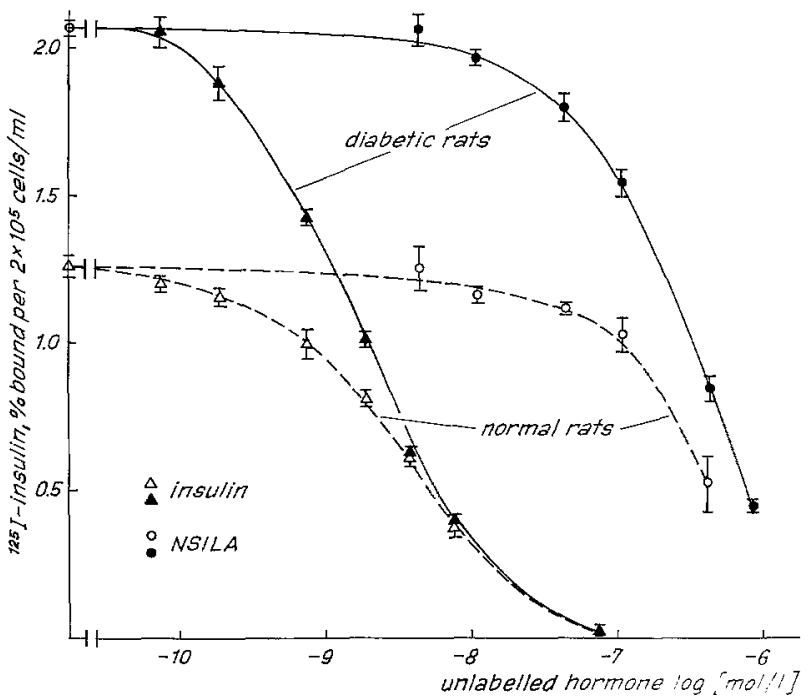

Fig. 4. Displacement of ${ }^{125} \mathrm{I}$-insulin from fat cells of normal and diabetic rats by insulin and NSILA. The preparation of NSILA used for displacement had a specific activity of $3.8 \mathrm{mU} / \mathrm{mg}$. Nonspecific binding of ${ }^{125} \mathrm{I}$-labelled insulin (between $10-20 \%$ of total binding) was subtracted. Incubation at $37^{\circ} \mathrm{C}$ lasted for $45 \mathrm{~min}$. (3 different experiments, brackets give the S.E.M.)

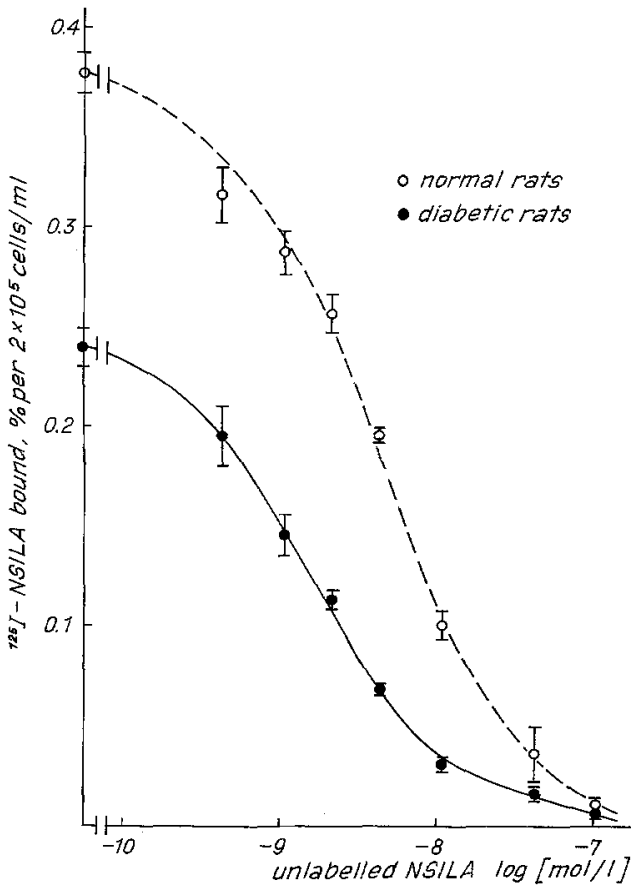

Fig. 5. Displacement of ${ }^{125}$-NSILA from fat cells of normal and diabetic rats by NSILA. The NSILA preparation used for displacement had a specific activity of $3.8 \mathrm{mU} / \mathrm{mg}$. The incubation at $37^{\circ} \mathrm{C}$ lasted for $45 \mathrm{~min}$. Nonspecific binding between $20 \%$ and $30 \%$ of total binding was subtracted ( 3 different experiments in duplicates, brackets give the S.E.M.)

came possible to study the interaction between the hormone and its binding site on the membrane [22]. Binding studies with ${ }^{125} \mathrm{I}$-monoiodinated insulin, which retains most, if not all, of the biological activity of unlabelled insulin [7], offered the chance to examine whether an impairment of the first step of 
Table 1. Enhancement of binding of ${ }^{125}$ I-NSILA by increasing amounts of unlabelled insulin

\begin{tabular}{|c|c|c|c|c|}
\hline unlabelled insulin $(\mathrm{Mol} / \mathrm{l})$ & 0 & $7.5 \times 10^{-11}$ & $7.5 \times 10^{-10}$ & $7.5 \times 10^{-9}$ \\
\hline \multicolumn{5}{|l|}{ Fat cells of normal rats: } \\
\hline $\begin{array}{l}\text { specifically bound }{ }^{125} \text { I-NSILA ( } \% \text { of added }{ }^{125} \text { I-NSILA per } \\
2 \times 10^{5} \text { cells) }\end{array}$ & $0.38 \pm 0.01$ & $0.81 \pm 0.03$ & $1.06 \pm 0.05$ & $1.05 \pm 0.05$ \\
\hline$\%$ above max. specific binding $(100 \%)$ & 0 & 114 & 182 & 178 \\
\hline \multicolumn{5}{|l|}{ Fat cells of diabetic rats: } \\
\hline $\begin{array}{l}\text { specifically bound }{ }^{125} \text { I-NSILA ( } \% \text { of added }{ }^{125} \text { I-NSILA per } \\
2 \times 10^{5} \text { cells) }\end{array}$ & $0.24 \pm 0.01$ & $0.31 \pm 0.01$ & $0.34 \pm 0.02$ & $0.35 \pm 0.01$ \\
\hline$\%$ above max. specific binding ( $100 \%)$ & 0 & 28 & 42 & 46 \\
\hline
\end{tabular}

Incubation at $37^{\circ} \mathrm{C}$ lasted for $45 \mathrm{~min}$. Nonspecific binding of ${ }^{125} \mathrm{I}$-NSILA was determined in the presence of $2.1 \times 10^{-7} \mathrm{M}$ unlabelled NSILA, and this value was subtracted. Nonspecific binding of ${ }^{125}$ I-NSILA in the presence of an excess of unlabelled NSILA was not changed when unlabelled insulin $\left(7.5 \times 10^{-9} \mathrm{M}\right)$ was also added. The values give the mean of the results of 5 to 8 incubations (from 2-3 experiments) and the S. E.M.

insulin action, i. e. binding to its receptor may be responsible for "insulin resistance" of diabetic adipose tissue. This might involve a decrease in the number of insulin receptors per cell and/or reduction in their affinity for insulin. The data reported in the literature [5] and those presented in this paper indicate that this is not the case. However, whereas Vann Bennett et al. [5] did not find any change in the number or in the affinity of the insulin receptors in fat cells from streptozotocin-diabetic rats we observed a 1.7-fold increase in specific receptor binding of insulin and a two-fold increase in the apparent affinity of the insulin receptor (Fig. 4).

Both phenomena might constitute part of a regulatory mechanism by which the diabetic fat cell tries to compensate for and adapt to the lack of insulin. They also fit into the concept of "up-and down-regulation" of insulin receptors [9]. Downregulation has been reported for fat cells [6] and monocytes [8] in hyperinsulinaemic states, up-regulation for liver membranes in congenital diabetes [10].

The observation that basal glucose transport in diabetic fat cells was enhanced is surprising and remains unexplained (Figs. 2, 3) but it could also fit with this concept. Nevertheless, this upward regulation of insulin receptors by no means compensated for the lack of insulin: the basal rates of $1{ }^{14} \mathrm{C}-\mathrm{glu}-$ cose oxidation (Fig. $1 \mathrm{a}$ ) and of ${ }^{14} \mathrm{C}-\mathrm{U}$-glucose incorporation into total lipids were significantly lower in diabetic than normal fat cells. In the presence of insulin diabetic fat cells were much less responsive to the acute action of the hormone than normal cells, both metabolically (Figs. $1 \mathrm{a}$ and $1 \mathrm{~b}$ ) and in terms of glucose transport (Figs. $2 \mathrm{a}$ and $3 \mathrm{a}$ ). Thus, the increase in the number and affinity of the insulin receptor (Fig. 4) cannot make up for the metabolic defect caused by prolonged lack of insulin. The decreased responsiveness of the diabetic fat cell to insulin is unlikely to be due to an impairment of one of the first steps of insulin action, but rather to a defect in the metabolic pathway of glucose caused by insulin deficiency. Stansbie et al. [23] have reported that pyruvate dehydrogenase (PDH) activity is markedly decreased in diabetic adipose tissue. Decreased levels of PDH appear to be rate-limiting in diabetic adipose tissue for glucose incorporation into lipids (Fig. 1 b) and for glucose oxidation (Fig. 1 a) via the pentose phosphate shunt. In diabetic adipocytes an apparent dissociation between insulin binding and insulin stimulated glucose transport was observed (Figs. 4 and $3 \mathrm{a}$ ): whereas insulin binding and the apparent affinity of the insulin receptor were increased when compared to normal cells, the stimulation of efflux of 3-0-methylglucose by insulin took off more slowly than in normal cells after addition of the hormone.

In the metabolic as well as in the efflux-studies NSILA and insulin behaved similarly: like insulin, NSILA exerted only weak acute metabolic effects on diabetic fat cells. Stimulation of ${ }^{14} \mathrm{C}$-oxidation from $1{ }^{14} \mathrm{C}$-glucose was less than twofold with both hormones compared to an 8-fold stimulation of normal cells (Fig. 1 a). ${ }^{14} \mathrm{C}-\mathrm{U}$-glucose incorporation into total lipids was less than 1.3-fold compared to an almost 6-fold stimulation in normal adipocytes (Fig. 1 b).

However, as described earlier [15], between 50-100 times more NSILA than insulin (on a molar basis) is required to elicit quantitatively similar effects. In accordance with this, NSILA was approximately 90 times less potent than insulin in displacing labelled insulin (Fig. 4). The efflux kinetics in the presence of insulin and NSILA were identical. This held true for adipocytes from normal rats (Figs. $2 \mathrm{a}$, b), as well as for adipocytes from diabetic rats (Figs. $3 \mathrm{a}, \mathrm{b}$ ). These results together strongly indicate that NSILA acts via the insulin binding site, but that the affinity of the insulin binding site for NSILA is much lower than for insulin itself. Additional 
evidence for the existence of a separate NSILA binding site is presented in Figure 5 and Table 1: 1. whereas diabetic fat cells bound more insulin than normal fat cells, binding of labelled NSILA by diabetic cells was reduced (Fig. 5). However, the apparent affinity of the NSILA binding site was 2.5 times higher in diabetic adipocytes than in normal cells. It is unlikely that differences in the degradation rate of the hormones in normal and diabetic adipocytes were responsible for the differences in the binding of these hormones, since the increase in insulin binding and the decrease in NSILA binding to diabetic adipocytes were also observed at lower temperature $\left(24^{\circ} \mathrm{C}\right.$, not shown). 2. Insulin did not displace labelled NSILA, but rather increased its binding. This could be observed at very low insulin concentrations $(10 \mu \mathrm{U} / \mathrm{ml})$. Whether this effect is to be interpreted in terms of positive cooperativity or whether insulin blocks the degradation of labelled NSILA is presently not known. The increase in NSILA binding in the presence of insulin was considerably lower in diabetic $(+46 \%)$ than in normal $(+$ $178 \%$ ) fat cells (Table 1 ).

All the known metabolic effects exerted by NSILA on adipose tissue are qualitatively identical with those of insulin [11, 12]. The results presented here favour the concept that both hormones act via the insulin receptor. The metabolic significance of the NSILA binding site in fat cells remains to be elucidated.

\section{References}

1. Froesch, E. R. In: A. E. Renold, G. F. Cahill (Eds.): Handbook of Physiology. V. Adipose tissue: Fructose metabolism in adipose tissue from normal and diabetic rats pp. 281-293. Washington: American Physiological Society 1965

2. Winegrad, A.J., Renold, A. E.: Studies on rat adipose tissue in vitro. 1. Effects of insulin on the metabolism of glucose, pyruvate and acetate. J. Biol. Chem. 233, 267-272 (1958)

3. Junod, A., Lambert, A. E., Orci, L., Pictet, R., Gonet, A. E., Renold, A.E.: Studies of the diabetogenic action of streptozotocin. Proc. Soc. Exp. Biol. Med. 126, 201-205 (1967)

4. Zapf, J., Feuerlein, D., Waldvogel, M., Froesch, E. R.: Increased sensitivity of diabetic rat adipose tissue towards the lipolytic action of epinephrine. Diabetologia 11, 509-516 (1975)

5. Vann Bennett, G., Cuatrecasas, P.: Insulin receptor of fat cells in insulin-resistant metabolic states. Science 176, 805-806 (1972)

6. Freychet, P., Laudat, M.H., Laudat, P., Rosselin, G., Kahn, C. R., Gorden, P., Roth, J.: Impairment of insulin binding to the fat cell plasma membrane in the obese hyperglycemic mouse. FEBS Lett. 25, 339-342 (1972)

7. Freychet, P.: Interactions of polypeptide hormones with cell membrane specific receptors: Studies with insulin and glucagon; Minkowski Award Lecture 1975. Diabetologia 12, 83-100 (1976)

8. Olefsky, J.M.: Decreased insulin binding to adipocytes and circulating monocytes from obese subects. J.Clin. Invest. 57, 1165-1172 (1976)

9. Soll, H.S., Kahn, C.R., Neville, M.D., Roth, J.: Insulin re- ceptor deficiency in genetic and acquired obesity. J. Clin. Invest. 56, 769-780 (1975)

10. Hepp, K.D., Langley, J., van Funcke, H.J., Renner, R., Kemmler, W.: Increased insulin binding capacity of liver membranes from diabetic chinese hamsters. Nature 258, 154 (1975)

11. Oelz, O., Froesch, E. R., Bünzli, H.F., Humbel, R.E., Ritschard, W. J.: Antibody-suppressible and nonsuppressible insulin-like activities; In: A. E. Renold, G. F. Cahill (Eds.): Handbook of Physiology, Section 7, Vol. 1, pp. 685-702. Washington: American Physiological Society 1972

12. Zapf, J., Mäder, M., Waldvogel, M., Froesch, E. R.: Nonsuppressible insulin-like activity: biological activity and receptor binding. Isr. J. Med. Sci. 11, 664-678 (1975)

13. Rinderknecht, E., Humbel, R.E.: Polypeptides with NSILA and cell growth promoting activity in human serum - isolation, chemical characterization and some biological properties of forms I and II. Proc. Natl. Acad. Sci. USA 73, 2365-2369 (1976)

14. Rinderknecht, E., Humbel, R. E.: Amino-terminal sequences of two polypeptides from human serum with nonsuppressible insulin-like and cell growth promoting activities: Evidence for structural homology with insulin B chain. Proc. Natl. Acad. Sci. USA 73, 4379-4381 (1976)

15. Schoenle, E., Zapf, J., Froesch, E.R.: Binding of nonsuppressible insulin-like activity (NSILA) to isolated fat cells: evidence for two separate membrane acceptor sites. FEBS Lett. 67, 175-179 (1976)

16. Zapf, J., Mäder, M., Waldvogel, M., Schalch, D. S., Froesch, E. R.: Specific binding of nonsuppressible insulin-like activity to chicken embryo fibroblasts and to a solubilized fibroblast receptor. Arch. Biochem. Biophys. 168, 630-637 (1975)

17. Rodbell, M.: Metabolism of isolated fat cells. 1. Effects of hormones on glucose metabolism and lipolysis. J. Biol. Chem. 239, 375-380 (1964)

18. Gliemann, J., Oesterlind, K., Vinten, J., Gammeltoft, S.: A procedure for measurement of distribution spaces in isolated fat cells. Biochim. Biophys. Acta 286, 1-9 (1972)

19. Gammeltoft, S., Gliemann, J.: Binding and degradation of ${ }^{125}$ I-insulin by isolated rat fat cells. Biochim. Biophys. Acta 320, 16-32 (1973)

20. Gliemann, J., Gammeltoft, S., Vinten, J.: Time course of insulin receptor binding and insulin induced lipogenesis in isolated rat fat cells. J. Biol. Chem. 250, 3368-3374 (1975)

21. Vinten, J., Gliemann, J., Oesterlind, K.: Exchange of 3-0-methylglucose in isolated fat cells: Concentration dependence and effect of insulin, J. Biol. Chem. 251, 794-800 (1976)

22. Cuatrecasas, P.: Insulin receptor interactions in adipose tissue cells: Direct measurement and properties. Proc. Natl. Acad. Sci. USA 68, 1264-1268 (1971)

23. Stansbie, D., Denton, R. M., Bridges, B. J., Pask, H. T., Randle, P.J.: Regulation of pyruvate dehydrogenase and pyruvate dehydrogenase phosphate phosphatase activity in rat epididymal fat pads; Effects of starvation, alloxan diabetes and high-fat diet. Biochem. J. 54, 225-235 (1976)

24. Bürgi, H., Müller, W.A., Labhart, A. and Froesch, E. R.: Nonsuppressible insulin-like activity of human serum. 1. Physicochemical properties, extraction and partial purification. Biochim. Biophys. Acta 121, 349-359 (1966)

Received: October 28, 1976, and in revised form:

January 21, 1977

Prof. E. R. Froesch

Metabolic Unit

Department of Medicine

Kantonsspital Zürich

Rämistraße 100

CH-8091 Zürich, Switzerland 